\title{
Purchasing practice of the consumers towards ready to eat food products
}

Author for Correspondence :

\section{VIJAYETA PRIYADARSHNI}

Department of Home Science,

Govt. Women's College, KEONJHAR (ODISHA) INDIA

\begin{abstract}
Recent trends in final food demand show that the concept of food has undergone a radical transformation in recent years. The diversification of food away from traditional products and in convergence with western style is responsible for changes in the whole food system. This paper aims to provide comprehensive approach to the consumer purchasing behaviour towards processed ready to eat and ready to cook food products. It thus focused on knowing the perception of the consumers towards Ready-to-Eat and ready to cook food and the impact of factors on their purchase intention. There existed an ambiguity of what Ready-to-Food is, as different sources provided with different meanings. In order to derive a niche expertise of derived findings, the research was restricted to only branded ready to eat and ready to cook food products and to Consumers who were aware about these food products. A sample of 110 respondents has been taken under convenient sampling technique in Bhubaneswar city, Odisha. The study reveals that majority of the respondents have planned decision in purchasing instant food products. Television plays a major role in providing information about instant food products.
\end{abstract}

KEY WORDS: Processed food, Ready to eat/cook food, Purchase behaviour, Consumer

- HOW TO CITE THIS PAPER : Priyadarshini, Vijayeta (2015). Purchasing practice of the consumers towards ready to eat food products. Asian J. Home Sci., 10 (2) : 290-295. 